\title{
Gallesia integrifolia (Spreng.) Harms. Growth Under Different Shade and Water Availability Conditions
}

\author{
Taysi Pereira Firmino ${ }^{1}$ () 0000-0002-6849-4460 \\ Caroline Barbeiro ${ }^{1}$ (1) 0000-0002-7351-4470 \\ Mariza Barion Romagnolo ${ }^{1}$ (1) 0000-0002-7529-3624 \\ Lindamir Hernandez Pastorini ${ }^{1}$ (ㄷ) 0000-0003-4679-4718
}

\begin{abstract}
Our study sought to evaluate parameters of mycorrhizal growth and colonization of Gallesia integrifolia under different light and water availability conditions. The experiment was conducted in a greenhouse, with the following treatments: three light levels ( $0 \%, 50 \%$ and $80 \%$ shading), and two water regimes (watering daily and twice a week), in a completely randomized experimental design. The results showed that the plants kept under $50 \%$ shading and the ones kept under full light, both watered daily, had the best performance. Mycorrhizal association was observed in all treatments, which favored the establishment of seedlings even in environments with less water availability. G. integrifolia showed acclimation to higher levels of shading and lower availability of water, which may be related to the species plasticity and its wide distribution.
\end{abstract}

Keywords: leaf area, mycorrhizal association, dry mass, water stress, shading.

\section{INTRODUCTION AND OBJECTIVES}

Gallesia integrifolia (Spreng.) Harms. (Phytolaccaceae) is a Brazilian native tree known as "pau d'alho" ("garlic wood", due to its strong garlic smell), occurring from Bahia to Paraná and characteristic of the Semideciduous Forest and the Paraná basin. It is a perennial, heliophile, selective hygrophyte species that occurs in deep, humid and highly fertile soils (Lorenzi, 2014).

Forest species have severe limitations to propagation, since information on their ecophysiological characteristics is scarce (Borges et al., 2014). Identifying the factors that affect survival and early growth of plants in the field is one of the major problems of seedling producers (Lima et al., 2008). Water availability and light are important environmental factors that influence plant growth.

Luminosity is a determinant factor for the emergence and growth of plants due to its influence on photosynthesis (Cavatte et al., 2009). Light is an indicator of the environment where the plant grows, which can be measured by its intensity, quality, and direction. It's an essential energy source for photosynthesis and consequential sugar production (Kozuka et al., 2005). Plants perceive changes in light quality through photoreceptors, such as phytochrome. These photoreceptors modulate seedling growth according to light quality. Light quality and intensity are important for the production of seedlings, since they control plant metabolism, growth, and development. These factors can also cause morphophysiological changes in the plant (Costa et al., 2018; Meira et al., 2012). In addition to light intensity, water deficiency can also change plant behavior depending on the duration, the severity of the deficit, and the plant genotype (Santos \& Carlesso, 1998).

Plant growth efficiency is related to its ability to acclimatize to different environmental conditions, especially as seedlings (phase that covers the vegetable from the germination of the seed until the formation of the first leaf or eophyll) (Caron et al., 2010; Souza, 2009). Many growth variables can be used to evaluate the behavior of forest seedlings regarding the availability of light and water. These variables include the dry mass of the aerial, root and leaf areas, as well as plant height.

${ }^{1}$ Universidade Estadual de Maringá (UEM), Maringá, PR, Brasil 
Mycorrhizal fungi are known to influence plant growth by participating in nutrient cycling and soil carbon storage (Terrer et al., 2016). Plants provide carbohydrates, obtained by photosynthesis, from the leaves to the colonized roots through the phloem and, in turn, the fungus transfers water and nutrients from the soil to the plants (Garcia et al., 2016). Such interactions, frequent in tropical soils (Smith \& Read, 2008), give the host plant greater tolerance to environmental stresses and, therefore, to water stress (Beltrano \& Ronco, 2008). This higher tolerance may be related to a greater contact of the root with the soil, considering that the mycorrhizal association changes root architecture, water, and nutrient absorption, which enhance tolerance to water stress (Pozo et al., 2015).

The association of the mycorrhizal fungus with the roots also improves growth and nutrition of the seedlings due to the greater absorption of nutrients, mainly phosphorus (Rodrigues et al., 2018), favoring its establishment in the field.

The relationship of abiotic factors such as water availability and light with mycorrhizal colonization remains little studied. Our research group has found that Gallesia integrifolia depends on the mycorrhizal association (unpublished data). Considering the importance of this association in the establishment of forest species (Rodrigues et al., 2018), our study sought to evaluate growth and mycorrhizal colonization of plants kept in different conditions of light and water availability.

\section{MATERIALS AND METHODS}

We collected brownish samaras from five parent trees of Gallesia integrifolia (Spreng.) Harms located at the Caiuá Ecological Station, in August 2014. This conservation unit is located in the municipality of Diamante do Norte, northwest of Paraná State (PR), between coordinates $52^{\circ} 49^{\prime}$ to $52^{\circ} 53^{\prime}$ $\mathrm{W}$ and $22^{\circ} 34^{\prime}$ to $22^{\circ} 37^{\prime} \mathrm{S}$ and altitude ranging from 240 to $380 \mathrm{~m}$ (IAP, 1997). The native vegetation belongs to the Atlantic Forest Biome and the Semidecidual Seasonal Forest.

The samaras were taken to the Laboratory of Plant Physiology of the Universidade Estadual de Maringá and processed by removing the wings to obtain the seeds.

Latosol soil collected from the B horizon of the campus of the Universidade Estadual de Maringá was used for the substrate. It was initially dried outdoors before being sieved to remove particulate organic matter, then fertilized with P300 (mg.dm ${ }^{-3}$ soil). Subsequently, 180 pots were prepared. Each pot received $1 \mathrm{~kg}$ of substrate and five seeds. After emergence, only one seedling per pot was maintained.

The experiment was conducted in greenhouse with the treatments: 3 light intensities (0\%, 50\% and $80 \%$ shading) and 2 water regimes (plants irrigated daily and plants irrigated twice a week). Light was measured with a luxmeter standardized for all conditions, over three days at 10 a.m., 12 p.m., and 4 p.m. The measurements were repeated 3 times at intervals of 30 seconds, on a 70-cm-high bench. The mean light intensity data were 2207.0 lux for the full light environment, 762.2 lux for $50 \%$ shading, and 2.4 lux for $80 \%$ shading.

Sixty days after differentiation of the first pair of true leaves, the plants were divided into plants watered daily and plants watered twice a week, with $50 \mathrm{~mL}$ of tap water. Thus, the G. integrifolia plants were maintained in the following treatments: $0 \%$ shade and irrigated daily ( $0 \%$ ID); $0 \%$ shade and irrigated twice a week ( $0 \%$ IT); $50 \%$ shade and irrigated daily (50\% ID); 50\% shade and irrigated twice a week ( $50 \%$ IT); $80 \%$ shade and irrigated daily ( $80 \%$ ID); and $80 \%$ shade and irrigated twice a week ( $80 \%$ IT). The shading levels were obtained by using a shade cloth according to the manufacturer's recommendations. For water availability, the plants watered daily were kept at the field capacity and plants watered twice a week were kept at $45 \%$ of water compared to the control. The pots filled with the soil were watered to the complete saturation and, after drainage, each pot was weighed to obtain the weight at total water capacity of soil.

Growth evaluation was conducted at three times: 30 , 60 , and 90 days after the beginning of the water treatment (DAWT). We randomly selected 10 plants from each treatment (five were used to assess mycorrhizal colonization and five to determine the dry matter and other growth parameters), totaling 60 plants evaluated for each time. To remove the plants without damage, the bags were vertically cut down and the soil was removed with running water to avoid the loss of root fragments. Measurements were taken for the following morphological variables: height $(\mathrm{H})$, primary root length (RL), collar diameter (CD), leaf dry mass (LDM), root dry mass (RDM), stem dry mass (STDM), shoot dry mass (SDM), total dry mass (TDM), leaf number (LN), and leaf area (LA) at 30 and 90 days. Root dry mass/shoot dry mass ratio (RDM/SDM), root dry mass/total dry mass (RDM/ TDM), leaf dry mass/total dry mass (LDM/TDM), stem dry mass/total dry mass (STDM/TDM), shoot dry mass/total dry mass (SDM/TDM).

Height and root length were measured with a ruler graduated in millimeters and collar diameter with a digital caliper. Plant height was measured from the root collar to the apex of the plant. To evaluate the mass, the plants were separated into roots, stem and leaves, placed in labeled paper bags, and incubated in an oven at $60^{\circ} \mathrm{C}$ for 7 days. The dry mass of the different organs was weighed on a MARK/M214AI analytical balance. Leaf number was determined by counting the fully expanded leaves in each plant. 
Leaf area (LA) was determined from five plants of each treatment. Fully expanded leaves of each plant were scanned and the leaf areas were measured using the Image-Pro PLUS ${ }^{\circ}$ software. The leaf area ratio (LAR) was determined from leaf area (LA) values expressed in $\mathrm{cm}^{2}$ and total dry mass (TDM) expressed in $\mathrm{g}$. The height/dry mass ratio of the shoot was obtained from the plant height $(\mathrm{H})$ and shoot dry mass (SDM) values.

We randomly collected five plants of each treatment at each time and separated the roots to assess root colonization by arbuscular mycorrhizal fungi. The roots were washed in tap water to remove substrate and were preserved in $50 \%$ ethanol. Then, roots were washed in fresh water and incubated in a water bath in tubes filled with $10 \% \mathrm{KOH}$ for clearing of the cortex. Roots were washed again in tap water and acidified with $5 \% \mathrm{HCl}$. Afterwards, they were stained with trypan blue in a water bath according to Phillips \& Hayman (1970) and stored in glass jars containing preservative solution until analysis. Root colonization was evaluated using a stereoscope microscope. In the samples in which clearing was insufficient to observe the root cortex, the roots were mounted on slides and observed in an optical microscope, and the quantification of colonization followed the criteria of Trouvelot et al. (1986). The percentage of roots colonized by arbuscular mycorrhizal fungi was determined using a stereoscopic microscope, based on records of presence or absence of characteristic intra-radicular structures such as vesicles, hyphae, and arbuscules by the gridline intersect method (Giovannetti \& Mosse, 1980).

The experiment was arranged in a $(3 \times 2)$ factorial design with three levels of light intensity $(0 \% ; 50 \%$ and $80 \%$ of shading) and two levels of water availability (plants watered daily and plants watered twice a week). All growth parameters were subjected to analysis of variance, and the means were compared by Tukey's test at $5 \%$ probability, using the Statistica 7.0 software.

\section{RESULTS AND DISCUSSION}

The seedlings of $G$. integrifolia showed variation in growth due to different levels of light intensity and water availability. For most of the parameters analyzed, light was the factor that most influenced plant growth over the experimental period. At 30 days, the analysis showed interaction between light and water availability for the parameters RDM, TDM, RDM/SDM, RDM/TDM, LDM/TDM, STDM/TDM and SDM/TDM. At 90 days, interaction was observed for the parameters STDM, SDM, CD, STDM/TDM, LA and LAR (Table 1). At 60 days, no interaction was found for the factors, therefore, they were not described.
Table 1. Result of the factorial analysis regarding to the effect of light and water availability and their interaction on the growth parameters of Gallesia integrifolia at 30 and 90 days.

\begin{tabular}{|c|c|c|c|c|}
\hline \multirow{2}{*}{$\begin{array}{l}\text { Period } \\
\begin{array}{l}\text { Parameters/Sources of } \\
\text { variation }\end{array}\end{array}$} & \multicolumn{2}{|c|}{30 days } & \multicolumn{2}{|c|}{90 days } \\
\hline & $\mathbf{L} \times \mathbf{W}$ & SD & $\mathbf{L} \times \mathbf{W}$ & SD \\
\hline Height $(\mathrm{cm})$ & ns & 2.85 & ns & 1.76 \\
\hline Root length $(\mathrm{cm})$ & ns & 4.27 & ns & 2.51 \\
\hline Leaf number & ns & 2.17 & ns & 2.51 \\
\hline Leaf dry mass (g) & ns & 0.11 & ns & 0.07 \\
\hline Stem dry mass (g) & ns & 0.08 & * & 0.13 \\
\hline Root dry mass (g) & * & 0.32 & ns & 0.34 \\
\hline Shoot dry mass (g) & ns & 0.15 & * & 0.16 \\
\hline Total dry mass (g) & * & 0.41 & ns & 0.42 \\
\hline Collar diameter $(\mathrm{mm})$ & ns & 0.59 & * & 0.47 \\
\hline $\begin{array}{l}\text { Root dry mass/shoot dry } \\
\text { mass ratio }\end{array}$ & * & 0.33 & ns & 0.25 \\
\hline $\begin{array}{l}\text { Root dry mass/total dry } \\
\text { mass ratio }\end{array}$ & * & 0.08 & ns & 0.07 \\
\hline $\begin{array}{l}\text { Leaf dry mass/total dry } \\
\text { mass ratio }\end{array}$ & * & 0.06 & ns & 0.05 \\
\hline $\begin{array}{l}\text { Stem dry mass/total dry } \\
\text { mass ratio }\end{array}$ & * & 0.05 & * & 0.04 \\
\hline $\begin{array}{l}\text { Shoot dry mass/total dry } \\
\text { mass ratio }\end{array}$ & * & 0.08 & ns & 0.07 \\
\hline Leaf area $\left(\mathrm{cm}^{2}\right)$ & ns & 2.57 & * & 1.98 \\
\hline Leaf area ratio $\left(\mathrm{cm}^{2} \mathrm{~g}^{-1}\right)$ & ns & 4.72 & * & 2.21 \\
\hline
\end{tabular}

${ }^{*} p \leq 0.05$ indicates that the results are significantly different. L: light; $\mathrm{W}$ : water availability; ns: non-significant; SD: standard deviation.

Seedling emergence started seven days after sowing. In general, at 30 and 90 days after the start of the water treatment, there was no significant difference of shoot height $(\mathrm{H})$, root length (RL), leaf number (LN), and leaf dry mass (LDM) for the seedlings maintained in the different treatments (Figures 1 and 2). Schwantes et al. (2013) also observed that the leaf number in seedlings of Gallesia integrifolia at different light levels showed no significant differences.

Concerning the root dry mass (RDM), interaction was recorded between the light effect and water availability (Table 1) after 30 days. The plants maintained in conditions under stress and without shade cloth $(0 \%$ IT) presented higher masses when compared with the other treatments (Table 2) due to plant growth alterations and resulted in a greater investment in the root mass. This allowed greater success in obtaining water. The plants kept under higher light availability had greater photosynthetic capacity (Nascimento et al., 2015; Wu et al., 2017). This promoted the transport of photosynthetic products to the roots and enabled larger root system areas. Increased photosynthetic capacity results from greater stomatal conductance, which increases $\mathrm{CO}_{2}$ concentration for carboxylation. Greater stomatal conductance also favors the increase of transpiration, and, consequently, greater root mass is needed for water absorption due to the evaporative demand. 

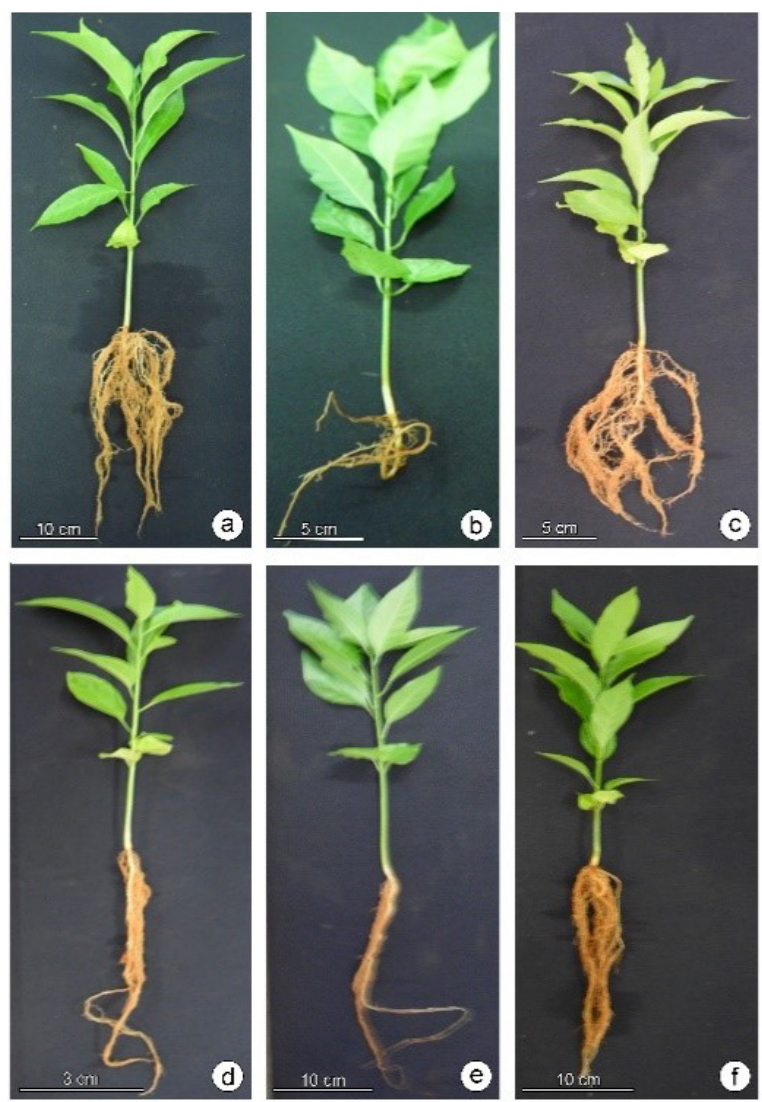

Figure 1. Gallesia integrifolia under different treatments at 30 days. (a) $50 \%$ ID, (b) $80 \%$ ID, (c) $0 \%$ ID, (d) $50 \%$ IT, (e) $80 \%$ IT, (f) $0 \%$ IT.
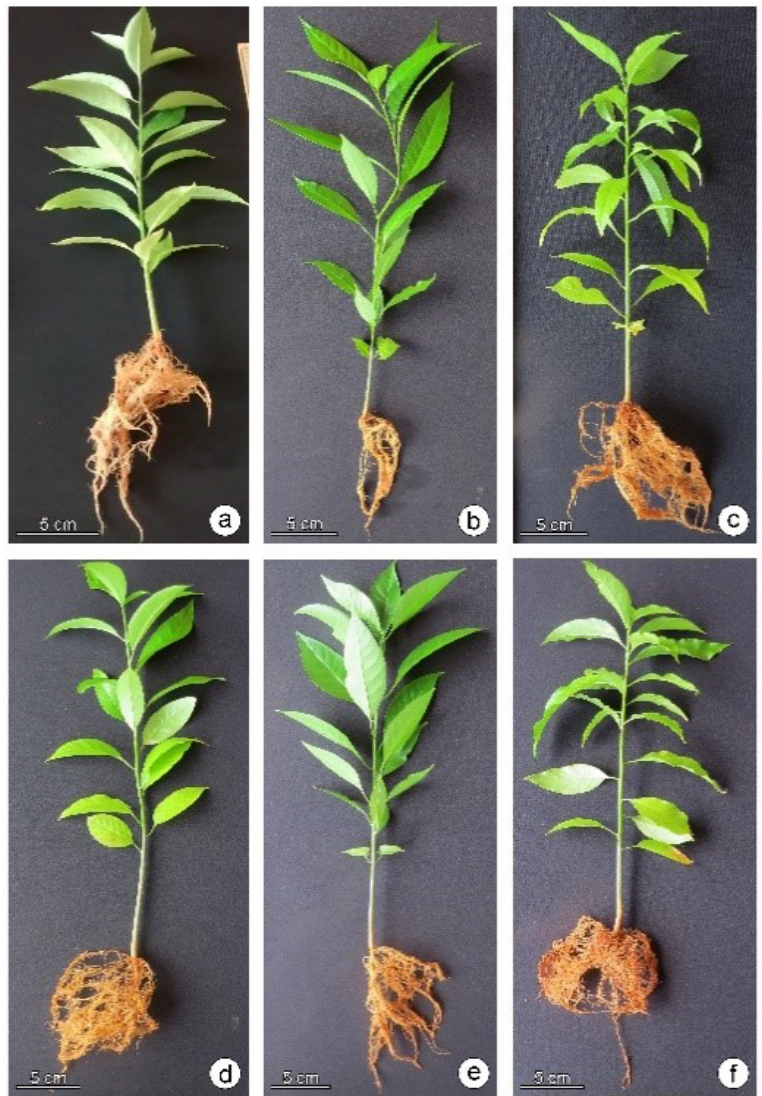

Figure 2. Gallesia integrifolia under different treatments at 90 days. (a) $50 \%$ ID, (b) $80 \%$ ID, (c) $0 \%$ ID, (d) $50 \%$ IT, (e) $80 \%$ IT, (f) $0 \%$ IT.

Table 2. Dry mass at 30 days of young Gallesia integrifolia plants kept in a greenhouse under $0 \%, 50 \%$ and $80 \%$ of shading, irrigated daily and irrigated twice a week.

\begin{tabular}{cccccccc} 
Parameter & $\mathbf{5 0 \%} \mathrm{ID}$ & $\mathbf{5 0 \%} \mathrm{IT}$ & $\mathbf{8 0 \%} \mathrm{ID}$ & $\mathbf{8 0 \%} \mathrm{IT}$ & $\mathbf{0 \%} \mathrm{ID}$ & $\mathbf{0 \%}$ IT \\
$\mathrm{RDM}(\mathrm{g})$ & $0.43 \mathrm{Ab}^{*}$ & $0.39 \mathrm{Ab}$ & $0.09 \mathrm{Ac}$ & $0.08 \mathrm{Ac}$ & $0.34 \mathrm{Bb}$ & $1.31 \mathrm{Aa}$ \\
$\mathrm{TDM}(\mathrm{g})$ & $1.16 \mathrm{Aa}$ & $0.92 \mathrm{Ab}$ & $0.41 \mathrm{Ac}$ & $0.40 \mathrm{Ac}$ & $1.03 \mathrm{Ba}$ & $2.09 \mathrm{Aa}$ \\
$\mathrm{RDM} / \mathrm{SDM}$ & $0.60 \mathrm{Aa}$ & $0.74 \mathrm{Ab}$ & $0.28 \mathrm{Ab}$ & $0.27 \mathrm{Ab}$ & $0.38 \mathrm{Bb}$ & $1.68 \mathrm{Aa}$ \\
$\mathrm{RDM} / \mathrm{TDM}$ & $0.37 \mathrm{Aa}$ & $0.42 \mathrm{Ab}$ & $0.21 \mathrm{Ab}$ & $0.20 \mathrm{Ac}$ & $0.26 \mathrm{Ba}$ & $0.60 \mathrm{Aa}$ \\
$\mathrm{LDM} / \mathrm{TDM}$ & $0.34 \mathrm{Ab}$ & $0.33 \mathrm{Ab}$ & $0.55 \mathrm{Aa}$ & $0.58 \mathrm{Aa}$ & $0.39 \mathrm{Ab}$ & $0.25 \mathrm{Bb}$ \\
$\mathrm{STDM} / \mathrm{TDM}$ & $0.28 \mathrm{Ab}$ & $0.24 \mathrm{Aa}$ & $0.23 \mathrm{Ab}$ & $0.21 \mathrm{Ab}$ & $0.35 \mathrm{Aa}$ & $0.15 \mathrm{Bc}$ \\
$\mathrm{SDM} / \mathrm{TDM}$ & $0.63 \mathrm{Ab}$ & $0.58 \mathrm{Ab}$ & $0.79 \mathrm{Aa}$ & $0.80 \mathrm{Aa}$ & $0.74 \mathrm{Aa}$ & $0.40 \mathrm{Bc}$ \\
\hline
\end{tabular}

${ }^{*}$ Data followed by the same letters are not significantly different by the Tukey's test at 5\%. Small letters compare light treatment in the same water condition. Capital letters compare plants ID and IT, in the same light condition. ID: irrigated daily; IT: irrigated twice a week; RDM: root dry mass; TDM: total dry mass; RDM/SDM: root dry mass/shoot dry mass ratio; RDM/TDM: root dry mass/total dry mass ratio; LDM/TDM: leaf dry mass/total dry mass ratio; STDM/TDM: stem dry mass/ total dry mass ratio; SDM/TDM: shoot dry mass/total dry mass ratio.

At 90 days, no interaction was found between the sources of variation, occurring only the effect of light. The plants under $0 \%$ and $50 \%$ shading, in both water conditions, had RDM $300 \%$ higher than the plants under $80 \%$ shading (Table 3, Figure 2). This increase in root mass can allow a greater absorption of water and nutrients, a strategy used by the plant to cope with high rates of transpiration and photosynthesis (Silva et al., 2007). Moreover, seedling exposure to high radiation suggests the allocation of photoassimilates preferentially to the root system, promoting greater mass gain of roots (Câmara \& Endres, 2008).

Total dry mass (TDM), at 30 days, showed interaction between the factors light and water availability, in which the plants in $0 \%$ and 50\% ID showed greater TDM (Table 2). Considering only water availability, a difference was observed between the treatments $0 \% \mathrm{ID}$ and $0 \% \mathrm{IT}$, with the largest TDM found for the treatment $0 \%$ IT (Table 2). At 90 days, no interaction was 
observed between the factors of variation (Table 1). The results of our study indicate that, at 30 days, G. integrifolia has greater mass accumulation in environments with higher light intensity, considering that the plants kept in the $0 \%$ shading received light intensity up to $99 \%$ higher than the plants under shading, according to the luxmeter readings. In general, plants maintained at higher luminous intensities have higher photosynthetic rates and higher photoassimilate production (Nascimento et al., 2015; Wu et al., 2017), which may contribute to the greater accumulation of dry biomass.

Stem dry mass (STDM) showed interaction between light and water availability only at 90 days (Table 1). The highest STDM was recorded for the treatment 50\% ID and the lowest for $80 \%$ ID (Table 3). For plants watered twice a week, the highest STDM was found for the treatments 50\% IT and $0 \%$ IT. When the plants under the same light condition and different water availability were compared, the highest STDM was found for the plants watered daily. Thus, negative effect of lower water availability and the effect of light on STDM was observed, with a negative influence of the treatment $80 \%$ shading on this parameter. According to Souza et al. (2017), plants under higher light intensities have high-capacity machinery for photosynthesis, contributing to the increase of the photosynthetic rate. Increase in photosynthesis results in more carbohydrate content in leaves, stem, and root, and, consequently, influences the increase in dry mass.

Table 3. Leaf dry mass, root dry mass, stem dry mass, stem dry mass/total dry mass, total dry mass, shoot dry mass, collar diameter, leaf area, leaf area ratio, height/shoot dry mass ratio of young Gallesia integrifolia plants kept in greenhouse conditions under $0 \%, 50 \%$ and $80 \%$ of shading and irrigated daily and irrigated twice a week.

\begin{tabular}{|c|c|c|c|c|c|c|}
\hline Parameter & $50 \%$ ID & $50 \%$ IT & $80 \%$ ID & $80 \%$ IT & 0\% ID & 0\% IT \\
\hline LDM (g) & $0.87 \mathrm{Aa}^{*}$ & $0.72 \mathrm{Aa}$ & $0.49 \mathrm{Ab}$ & $0.41 \mathrm{Ab}$ & $0.80 \mathrm{Aa}$ & $0.62 \mathrm{Aa}$ \\
\hline RDM (g) & $1.10 \mathrm{Aa}$ & $0.84 \mathrm{Aa}$ & $0.27 \mathrm{Ab}$ & $0.22 \mathrm{Ab}$ & $1.24 \mathrm{Aa}$ & $0.90 \mathrm{Aa}$ \\
\hline STDM (g) & $1.11 \mathrm{Aa}$ & $0.66 \mathrm{Ba}$ & $0.29 \mathrm{Ac}$ & $0.31 \mathrm{Ab}$ & $0.82 \mathrm{Ab}$ & $0.57 \mathrm{Ba}$ \\
\hline STDM/TDM & $0.36 \mathrm{Aa}$ & $0.26 \mathrm{Bb}$ & $0.28 \mathrm{Ab}$ & $0.33 \mathrm{Aa}$ & $0.30 \mathrm{Ab}$ & $0.27 \mathrm{Ab}$ \\
\hline TDM (g) & $3.09 \mathrm{Aa}$ & $2.22 \mathrm{Aa}$ & $1.06 \mathrm{Ab}$ & $0.94 \mathrm{Ab}$ & $2.86 \mathrm{Aa}$ & $2.09 \mathrm{Aa}$ \\
\hline SDM (g) & $1.98 \mathrm{Aa}$ & $1.38 \mathrm{Ba}$ & $0.79 \mathrm{Ac}$ & $0.72 \mathrm{Ab}$ & $1.61 \mathrm{Ab}$ & $1.20 \mathrm{Ba}$ \\
\hline $\mathrm{CD}(\mathrm{mm})$ & $6.00 \mathrm{Aa}$ & $4.50 \mathrm{Bb}$ & $3.80 \mathrm{Ac}$ & $3.40 \mathrm{Ac}$ & $5.60 \mathrm{Aa}$ & $5.60 \mathrm{Aa}$ \\
\hline LA $\left(\mathrm{cm}^{2}\right)$ & $19.96 \mathrm{Aa}$ & $21.36 \mathrm{Aa}$ & 19.77 Aa & $13.13 \mathrm{Bb}$ & $11.04 \mathrm{Ab}$ & $10.46 \mathrm{Ab}$ \\
\hline $\operatorname{LAR}\left(\mathrm{cm}^{2} \mathrm{~g}^{-1}\right)$ & $6.63 \mathrm{bA}$ & $8.56 \mathrm{bA}$ & $19.04 \mathrm{aA}$ & $14.08 \mathrm{aB}$ & $3.99 \mathrm{cA}$ & $5.02 \mathrm{cA}$ \\
\hline $\mathrm{H} / \mathrm{SDM}\left(\mathrm{cm} \mathrm{g}^{-1}\right)$ & $17.24 \mathrm{Ab}$ & $17.38 \mathrm{Ab}$ & $37.87 \mathrm{Aa}$ & $34.41 \mathrm{Aa}$ & $15.65 \mathrm{Ab}$ & $16.30 \mathrm{Ab}$ \\
\hline
\end{tabular}

* Data followed by the same letters are not significantly different by the Tukey's test at $5 \%$. Small letters compare light treatment in the same water condition. Capital letters compare plants ID and IT, in the same light condition. ID: irrigated daily; IT: irrigated twice a week; LDM: leaf dry mass; RDM: root dry mass; STDM: stem dry mass; STDM/TDM: stem dry mass/total dry mass ratio; TDM: total dry mass; SDM: shoot dry mass; CD: collar diameter; LA: leaf area; LAR: leaf area ratio; H/ SDM: height/shoot dry mass ratio.

At 90 days, we found that $G$. integrifolia seedlings under $80 \%$ shading had the lowest means of leaf dry mass (LDM), stem dry mass (STDM), and root dry mass (RDM) and, consequently, the lowest total dry mass (TDM) at both evaluation times. Feijó et al. (2009) reported higher growth of G. integrifolia seedlings when kept under $25 \%$ and $50 \%$ shading. However, the authors observed a significant reduction in growth when the seedlings were under $75 \%$ shading, which agrees with our findings for $80 \%$ shading, in which we found the lowest values for the growth variables dry mass of stem and shoot and the smallest collar diameter at 90 days (Table 3 ).

The factorial analysis showed no interaction of the variation factors on collar diameter of G. integrifolia seedlings at 30 days, with only the light effect occurring at this time. At 90 days after the beginning of the water treatment (DAWT), an interaction was observed between light and water availability on $\mathrm{CD}$ (Table 1), with the smallest diameter recorded in plants under $80 \%$ shading, regardless of water availability (Table 3). Reduction in the collar diameter of plants under $80 \%$ shading, regardless of water availability, was also found by Ferreira et al. (2012) and, according to Mota et al. (2012), a high correlation was observed between collar diameter and seedling survival after planting. Thus, the highest collar diameter found in plants kept under 50\% ID, 0\% ID, and 0\% IT (Table 3) may indicate a higher survival rate after planting.

The shoot dry mass (SDM), at 90 DAWT, was significantly higher for the plants under 50\% ID, followed by the plants under 0\% ID (Table 3), with significant interaction between light and water availability (Table 1). At 30 DAWT, no interaction was found between the sources of variation. The highest shoot dry masses correspond to more lignified and tough seedlings, capable of establishing with greater success 
in unfavorable environments, considering that the SDM indicates the seedling robustness (Gomes \& Paiva, 2006).

At 30 days DAWT, the highest means for the SDM/ TDM ratio were observed in plants under $80 \%$ shading. The lowest SDM/TDM ratio was found in plants exposed to the highest light intensity with lower water availability (Table 2), which may be related to the greater investment in RDM. The highest SDM/TDM ratio found in G. integrifolia seedlings under $80 \%$ shading reflects the greater investment of plants in height growth, with lower mass of leaves and roots at the growth beginning. At $90 \mathrm{DAWT}$, no interaction was observed between light and water availability on SDM/TDM (Table 1).

At 30 days DAWT, the RDM/SDM ratio was higher in the plants under 50\% ID when compared with the plants under $80 \%$ shading and $0 \%$, in the same water condition. However, the plants watered twice a week had the highest ratio in the treatment $0 \%$ IT (Table 2). Plants kept under $80 \%$ shading had the lowest RDM/TDM ratio. The highest RDM/TDM ratio in plants from environments more exposed to sunlight indicates a greater allocation of photoassimilates to the root system (Siebeneichler et al., 2008). Carvalho et al. (2006) reported that the highest root/shoot ratio and the lowest leaf area ratio in plants from environments more exposed to sunlight indicate that the biomass was distributed more preferentially to the roots than to the photosynthesizing organs. This allocation allows a greater absorption of water and nutrients, which is a strategy that would guarantee greater capacity to withstand the higher rates of photosynthesis and transpiration in environments more exposed to sunlight.

The highest LDM/TDM ratio was recorded for plants under $80 \%$ ID and $80 \%$ IT, at 30 days DAWT (Table 2). The other treatments were not significantly different. These results may be related to the lowest total dry mass found in the plants under $80 \%$ shading, reflecting a higher leaf investment, although no interaction of the factors light and water availability was observed on LDM at 30 days. However, this interaction was significant when assessing LDM regarding TDM (Tables 1 and 2).

A significant interaction was observed between light and water availability for the STDM/TDM ratio, at 30 and 90 days DAWT (Table 1). Considering, at 30 days, the plants watered daily, the highest STDM/TDM was found in plants under $0 \%$ ID, whereas the plants with lower water availability had the highest STDM/TDM in the treatment 50\% IT and lowest in the treatment $0 \%$ IT (Table 2). At 90 days, when comparing the plants watered daily, the lowest STDM/TDM was found in the plants under $80 \%$ shading, which is related to the lowest STDM found for these plants (Table 3).

Plants that grow in shaded environments usually have longer stems (Souza et al., 2017). Longer stems compensate for light deficiency and is an important mechanism of adaptation of the species. Stem growth is a valuable strategy plants use to escape conditions of low luminosity (Moraes Neto et al., 2000). In competition for light, plants adjust their architecture to allow their leaves to reach places with more sunlight availability for the lower strata. These architectural responses include accelerated stretching (of the hypocotyl, internodes, and petioles), upward leaf movement, and reduced shoot branching. These strategies are collectively named as "shadow avoidance syndrome". Shaded environments have a greater proportion of distant red light (FR). This involves a reduced red light / distant red light ratio (R: FR), which is perceived by phytochromes (Pierik \& De Wit, 2014). The reduction of the R: FR ratio decreases active phytochrome (phyB) levels. This promotes the expression of genes for auxin and gibberellin synthesis, as well as the consequential stem elongation (Casal, 2012).

However, G. integrifolia seedlings kept in the most shaded environment had the lowest STDM, which may indicate that these plants had thinner stems, providing lower stem mass for plants kept in more shaded environments, since no significant difference for the height was observed between plants kept in the different treatments (Table 1). This can also be confirmed by the higher H/SDM ratio observed in the plants kept under $80 \%$ shading, independent of water availability (Table 3), indicating a lower investment in shoot mass (stem and leaves) than in height.

At 30 days DAWT, we found no interaction of the sources of variation on LA. On the other hand, at 90 days, greater LA was observed for the plants under 50\% ID, 50\% IT, and $80 \%$ ID (Table 3). This indicates the effect of light on the increase of leaf area, increasing the chances of light capture and photosynthetic area (Siebeneichler et al., 2008).

The leaf area ratio (LAR) at 90 DAWT was highest for plants under $80 \%$ shading, which was established by the significant interaction between light and water availability (Table 3). LAR indicates the plant's investment in leaf area considering the total dry mass of the plant, which was determined by the highest LA in the plants under $80 \%$ ID and reduction in TDM. Souza et al. (2017) found that young plants of Enterolobium contortisiliquum growing under shade had larger leaf size and greater leaf area ratio $\left(\mathrm{cm}^{2} \mathrm{~g}^{-1}\right)$, indicating investment in larger leaves with thinner mesophyll, which makes the light capture in a shaded environment more efficient. This response was also recorded for $G$. integrifolia seedlings under $80 \%$ shading, with the lowest LDM and TDM and the highest LAR at 90 days (Table 3).

The arbuscular mycorrhizal association in young plants of G. integrifolia was observed in all treatments, and at 30 DAWT, the highest colonization percentage was found for plants kept under $0 \%$ ID and 0\% IT, and in plants under the treatment 50\% ID (Figure 3). 


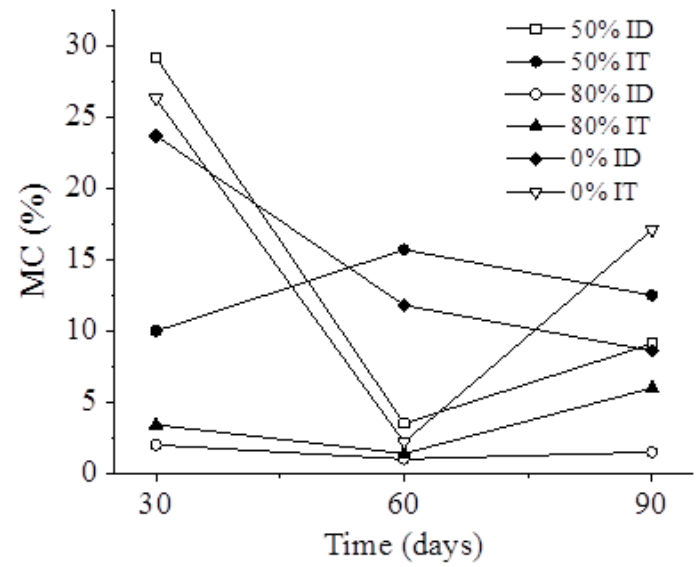

Figure 3. Mycorrhizal colonization (MC) - (\%) at 30, 60, and 90 days after the beginning of the water treatment.

At 60 days DAWT, there was a decrease in the colonized segments, and the plants kept in 0\% IT and 50\% IT showed the highest colonization rates, and at 90 days the highest colonization percentages were observed in plants under $0 \%$ IT and 50\% IT. The lowest values were found in plants kept under $80 \%$ shading, regardless of water availability (Figure 3), which may be associated with the reduction in root mass of plants kept under the highest level of shading.

The mycorrhizal association is characterized by nutritional changes between plant and fungi. The fungus provides the autotrophic host with mineral nutrients and water, promoting the growth of plants, in exchange, the host plant provides sugar from the photosynthesis (photoassimilates) to the heterotrophic symbiont (Garcia et al., 2016).

Braghirolli et al. (2012) reported that the carbon allocated to the roots is also used to maintain the symbioses established by plants with soil microorganisms, mainly nitrogen-fixing bacteria and arbuscular mycorrhizal fungi (AMF). Thus, the higher level of shading may have led to lower allocation of photoassimilates to the roots, also reducing the mass of the root system, compromising the mycorrhizal association (Konvalinková \& Jansa, 2016).

Mycorrhizal fungi are considered key components in the production of seedlings (Rodrigues et al., 2018). Moratelli et al. (2007) pointed out that plants under water restriction have a higher root/shoot ratio when colonized by native fungi. This was observed at 30 days, in which plants under $0 \%$ IT showed higher RDM/SDM ratio than plants under 0\% ID (Table 2), which may have ensured the initial establishment of these plants.

In our study, different light intensities and water availability significantly affected the colonization percentage in the plants subjected to the highest shading level. Therefore, light intensity is one of the factors that affect the mycorrhizal association with the plant (Moratelli et al., 2007), as well as water availability (Yooyongwech et al., 2016). Thus, seedlings of $G$. integrifolia could adapt to variations in the availability of resources regarding the association with arbuscular mycorrhizal fungi (AMF), which may favor the establishment of plants in environments with limiting water and light (Konvalinková \& Jansa, 2016; Pozo et al., 2015).

\section{CONCLUSIONS}

The mycorrhizal association of young garlic wood plants is affected by lower light availability, which is the factor that mostly affect plant growth. Despite showing favorable acclimatization capacity in conditions of higher levels of shading and water restriction, the recommended conditions for the cultivation of the G. integrifolia seedlings were 50\% ID and $0 \% \mathrm{ID}$, since they presented the best performance. This tendency may be related to the plant plasticity, which would justify its wide distribution, considering that the plant can be both pioneer and secondary.

\section{SUBMISSION STATUS}

Received: 19 Dec. 2018

Accepted: 9 July 2019

Associate editor: Marcos Gervásio Pereira

(1) 0000-0002-1402-3612

\section{CORRESPONDENCE TO}

\section{Taysi Pereira Firmino}

Universidade Estadual de Maringá (UEM), Av. Colombo, 5.790, bloco G 80, sala 101, CEP 87020-900, Maringá, PR, Brasil

e-mail: taysi_in@hotmail.com

\section{FINANCIAL SUPPORT}

Coordenação de Aperfeiçoamento de Pessoal de Nível Superior (CAPES) and Fundação Araucária.

\section{REFERENCES}

Beltrano J, Ronco MG. Improved tolerance of wheat plants (Triticum aestivum L.) to drought stress and rewatering by the arbuscular mycorrhizal fungus Glomus claroideum: effect on growth and cell membrane stability. Brazilian Journal of Plant Physiology 2008; 20(1): 29-37. 10.1590/S1677-04202008000100004

Borges VP, Costa MAPC, Ribas RF. Emergência e crescimento inicial de Tabebuia heptaphylla (Vell.) Toledo em ambientes contrastantes de luz. Revista Árvore 2014; 38(3): 523-531. 10.1590/ S0100-67622014000300015

Braghirolli FL, Sgrott AF, Pescador R, Uhlmann A, Stürmer SL. Fungos micorrízicos arbusculares na recuperação de florestas ciliares 
e fixação de carbono no solo. Revista Brasileira de Ciência do Solo 2012; 36: 733-743. 10.1590/S0100-06832012000300005

Câmara CA, Endres L. Desenvolvimento de mudas de duas espécies arbóreas: Mimosa caesalpiniifolia Benth. e Sterculia foetida L. sob diferentes níveis de sombreamento em viveiro. Floresta 2008; 38: 43-51.

Caron BO, Souza VQ, Cantarelli EB, Manfron PA, Behling A, Eloy E. Crescimento em viveiro de mudas de Schizolobium parahyba (Vell.) S. F. Blake. submetidas a níveis de sombreamento. Ciência Florestal 2010; 20(4): 683-689. 10.5902/198050982427

Carvalho NOS, Pelacani CR, Rodrigues MOS, Crepaldi IC. Crescimento inicial de plantas de licuri (Syagruscoronata (Mart.) Becc.) em diferentes níveis de luminosidade. Revista Árvore 2006; 30(3): 351-357. 10.1590/S0100-67622006000300005

Casal JJ. Shade avoidance. Arabidopsis Book 2012; 10: 1-19. 10.1199/ tab. 0157

Cavatte PC, Zonta JB, Lopes JC, Souza LT, Zonta JH, Cavatte RPQ. Germinação e vigor de sementes de cenoura em solo de mineração de calcário sob diferentes intensidades luminosas e adubações. Idesia 2009; 27(2): 25-32. 10.4067/S0718-34292009000200003

Costa IJS, Costa BNS, Assis FA, Martins AD, Pio LAS, Pasqual M. Growth and physiology of jelly palm (Butia capitata) grown under colored shade nets. Acta Scientiarum Agronomy 2018; 40(1): e35332. 10.4025/actasciagron.v40i1.35332

Feijó NSA, Mielke MS, Gomes FP, França S, Lavinsky AO. Growth hand photosynthetic responses of Gallesia integrifolia (Spreng.) Harms and Schinus terebinthifolius Raddi seedlings in dense shade. Agroforest System 2009; 77: 49-58. 10.1007/s10457-008-9190-x

Ferreira WN, Zandavalli RB, Bezerra AME, Medeiros Filho S. Crescimento inicial de Piptadenia stipulacea (Benth.) Ducke (Mimosaceae) e Anadenanthera colubrina (Vell.) Brenan var. cebil (Griseb.) Altshul (Mimosaceae) sob diferentes níveis de sombreamento. Acta Botanica Brasilica 2012; 26(2): 408-414. 10.1590/S0102-33062012000200016

Garcia K, Doidy J, Zimmermann SD, Wipf D, Courty PE. Take a trip through the plant and fungal transportome of mycorrhiza. Trends in Plant Science 2016; 21(11): 937-950. 10.1016/j.tplants.2016.07.010

Giovannetti M, Mosse B. An evaluation of techniques for measuring vesicular-arbuscular mycorrhizal infection in roots. New Phytologist 1980; 84(3): 489-500. 10.1111/j.1469-8137.1980.tb04556.x

Gomes JM, Paiva HN. Viveiros florestais: propagação sexuada. 3rd ed. Viçosa: UFV; 2006

Instituto Ambiental do Paraná - IAP. Plano de Manejo da Estação Ecológica do Caiuá, Diamante do Norte, PR. Paranavaí: IAP; 1997.

Konvalinková $\mathrm{T}$, Jansa J. Lights off for arbuscular mycorrhiza: on its symbiotic functioning under light deprivation. Frontiers in Plant Science 2016; 7: 782. 10.3389/fpls.2016.00782

Kozuka T, Horiguchi G, Kim GT, Ohgishi M, Sakai T, Tsukaya H. The different growth responses of the Arabidopsis thaliana leaf blade and the petiole during shade avoidance are regulated by photoreceptors and sugar. Plant and Cell Physiology 2005; 46(1): 213-223. $10.1093 / \mathrm{pcp} / \mathrm{pci0} 16$

Lima JD, Silva BMS, Moraes WS, Dantas VAV, Almeida CC. Efeitos da luminosidade no crescimento de mudas de Caesalpinia ferrea
Mart. ex Tul. (Leguminosae, Caesalpinoideae). Acta Amazonica 2008; 38(1): 5-10. 10.1590/S0044-59672008000100002

Lorenzi H. Árvores brasileiras: manual de identificação e cultivo de plantas arbóreas nativas do Brasil. 6th ed. Nova Odessa: Instituto Plantarum; 2014.

Meira MR, Martins ER, Manganotti SA. Crescimento, produção de fitomassa e teor de óleo essencial de melissa (Melissa officinalis) sob diferentes níveis de sombreamento. Revista Brasileira de Plantas Medicinais 2012; 14(2): 352-357. 10.1590/S1516-05722012000200015

Moraes Neto SP, Gonçalves JLM, Takaki M, Cenci S, Gonçalves JC. Crescimento de mudas de algumas espécies arbóreas que ocorrem na Mata Atlântica, em função do nível de luminosidade. Revista Árvore 2000; 24(1): 35-45.

Moratelli EM, Costa MD, Lovato PE, Santos M, Paulilo MTS. Efeito da disponibilidade de água e de luz na colonização micorrízica e no crescimento de Tabebuia avellanedae Lorentz exGriseb. (Bignoniaceae). Revista Árvore 2007; 31(3): 555-566. 10.1590/ S0100-67622007000300021

Mota LHS, Scalon SPQ, Heinz R. Sombreamento na emergência de plântulas e no crescimento inicial de Dipteryx alata Vog. Ciência Florestal 2012; 22(3): 423-431. 10.5902/198050986611

Nascimento KC, Pastorini LH, Romagnolo MB, Souza LA. Do Eugenia hiemalis seedling leaves under different light conditions develop phenotypic plasticity? Plant Ecology 2015; 216(11): 15711581. 10.1007/s11258-015-0540-2

Phillips JM, Hayman DS. Improved procedures for clearing roots and staining parasitic and vesicular-arbuscular mycorrhizal fungi for rapid assessment of infection. Transactions of the British Mycological Society 1970; 55(1): 158-161. 10.1016/S0007-1536(70)80110-3

Pierik R, De Wit M. Shade avoidance: phytochrome signalling and other aboveground neighbour detection cues. Journal of Experimental Botany 2014; 65(11): 2815-2824. 10.1093/jxb/ert389

Pozo MJ, López-Ráez JA, Azcón-Aguilar C, García-Garrido JM. Phytohormones as integrators of environmental signals in the regulation of mycorrhizal symbioses. New Phytologist 2015; 205: 1431-1436. 10.1111/nph.13252

Rodrigues LA, Barroso DG, Figueiredo FAMMA. Fungos micorrízicos arbusculares no crescimento e na nutrição mineral de mudas de Tectona grandis L. F. Ciência Florestal 2018; 28(1): 25-34. 10.5902/1980509831572

Santos RF, Carlesso R. Déficit hídrico e os processos morfológico e fisiológico das plantas. Revista Brasileira de Engenharia Agrícola e Ambiental 1998; 2(3): 287-294. 10.1590/1807-1929/agriambi.v2n3p287-294

Schwantes D, Klein J, Mezzalira EJ, Piva AL, Rossol CD, Scalon Filho $\mathrm{H}$ et al. Desenvolvimento de plantas jovens de Gallesia integrifolia submetidas a diferentes níveis de luminosidade. Revista Cultivando o Saber 2013; 6(2): 67-73.

Siebeneichler SC, Freitas GA, Silva RR, Adorian GC, Capellari D. Características morfofisiológicas em plantas de Tabebuia heptaphyilla (vell.) Tol. em condições de luminosidade. Acta Amazônica 2008; 38(3): 467-472. 10.1590/S0044-59672008000300011

Silva BMS, Lima JD, Dantas VAV, Moraes WS, Sabonaro DZ. Efeito da luz no crescimento de mudas de Hymenaea parvifolia 
Huber. Revista Árvore 2007; 31(6): 1019-1026. 10.1590/S010067622007000600006

Smith SE, Read DJ. Mycorrhizal symbiosis. 3rd ed. London: Academic Press; 2008.

Souza JP, Melo NMJ, Halfeld AD, Reis JN. Shading effects on leaf life span and functional traits in the widespread species Enterolobium contortisiliquum (Vell.) Morong. Acta Scientiarum Biological Sciences 2017; 39(1): 113-122. 10.4025/actascibiolsci.v39i1.33400

Souza LA. Morfologia anatomia vegetal: célula, tecidos, órgãos e plântula. Ponta Grossa: Editora UEPG; 2009.

Terrer C, Vicca S, Hungate BA, Phillips RP, Prentice IC. Mycorrhizal association as a primary control of the $\mathrm{CO}_{2}$ fertilization effect. Science 2016; 353(6294): 72-74. 10.1126/science.aaf4610
Trouvelot A, Kough JL, Gianinazzi-Pearson V. Mesure du taux de mycorhization VA d'un système radiculaire: recherche de méthodes d'estimation ayant une signification fonctionnelle. In: Gianinazzi S, Gianinazzi-Pearson V, editors. Mycorhizes: physiologie et genétique. Dijon: Inra; 1986. p. 217-220.

Wu J, Li J, Su Y, He Q, Wang J, Qiu Q, Ma J. A morphophysiological analysis of the effects of drought and shade on Catalpa bungei plantlets. Acta Physiologiae Plantarum 2017; 39: 80-90. 10.1007/ s11738-017-2380-2

Yooyongwech A, Samphumphuang T, Tisarum R, Theerawitaya C, Cha-um S. Arbuscular mycorrhizal fungi (AMF) improved water deficit tolerance in two different sweet potato genotypes involves osmotic adjustments via soluble sugar and free proline. Scientia Horticulturae 2016; 198: 107-117. 10.1016/j.scienta.2015.11.002 